\section{Etanercept Allergy and Anaphylaxis}

\section{To the Editor:}

Etanercept has been an effective, well tolerated medication with uncommon and usually acceptable adverse effects. We are aware of only 4 reports describing possible/probable etanercept allergy/anaphylaxis $1,2,3,4,5$. We describe 2 patients with allergic/anaphylactoid reactions to etanercept, review the literature, and comment on pertinent management issues.

A 49-year-old woman with a history of atopy and anaphylactoid/ angioedematous symptoms to soy milk developed rheumatoid arthritis (RA) in 2009. She was started on prednisone, minocycline, sulfasalazine, ibuprofen, and hydroxychloroquine, with a poor response. She was then prescribed etanercept $50 \mathrm{mg}$ weekly subcutaneously, which rendered her asymptomatic. However, after several months she reported increasingly frequent and severe episodes characterized by urticaria and swelling of the periorbital regions and her tongue within hours following administration of etanercept, requiring diphenhydramine, epinephrine, and corticosteroids. Etanercept was discontinued and there has been no recurrence of these events.

A 27-year-old woman presented in 2005 with persistent rash, fevers, arthritis, and elevated inflammatory markers; no other disorder was evident. Adult-onset Still's disease was diagnosed, and she began taking oral steroids. She did not respond to or developed adverse reactions to anakinra, methotrexate, and azathioprine, and began taking subcutaneous etaner- cept $25 \mathrm{mg}$ twice weekly. She reported episodes of facial swelling with periorbital edema, diffuse pruritic rash, and difficulty swallowing within hours after injection, requiring epinephrine and corticosteroids. Etanercept was discontinued and there has been no recurrence of these events.

We believe that our patients' allergic reactions were caused by etanercept. While we did not carry out blinded, controlled provocation challenges (and did not want to), both patients responded stereotypically, repeatedly, and specifically to prescribed doses of medication; reactions did not recur following cessation of etanercept and did not occur with other medications. We could not investigate immunologic sensitivity to medication. We interpret our patients' clinical stories as consistent with etanercept-induced anaphylactoid reactions. There is precedent, albeit uncommon, for this in the literature. Injection site reactions (pruritis, edema, and erythema) have been etanercept's most common side effects ${ }^{6}$. Systemic/ allergic reactions have not commonly been reported ${ }^{7,8}$. Discontinuation of treatment for systemic allergic reactions (dermatologic, infection) was more frequent for other anti-tumor necrosis factor- $\alpha$ (TNF- $\alpha$ ) antagonists than for etanercept ${ }^{9}$; acute systemic allergic reactions were more frequent with infliximab than with adalimumab or etanercept. The manufacturer reported $<2 \%$ of patients experiencing allergic reactions in clinical trials (when the drug was administered with solvent-containing L-arginine hydrochloride, itself potentially allergenic); angioedema occurred in postmarketing reports but without details ${ }^{1}$. Immediate adverse reactions in a large cohort of patients receiving anti-TNF agents reported no cases of

Table 1. Biologic agents used in the management of rheumatoid arthritis (RA).

\begin{tabular}{|c|c|c|c|c|c|c|c|}
\hline Case & $\begin{array}{l}\text { Sex/age, } \\
\text { yrs }\end{array}$ & Diagnosis & $\begin{array}{c}\text { Biologic } \\
\text { Associated } \\
\text { with Allergy- } \\
\text { Anaphylaxis }\end{array}$ & $\begin{array}{c}\text { Disease } \\
\text { Duration } \\
\text { Prior to } \\
\text { Etanercept, mo }\end{array}$ & $\begin{array}{c}\text { Duration of } \\
\text { Etanercept Use } \\
\text { Prior to } \\
\text { Reactions, mo }\end{array}$ & $\begin{array}{c}\text { History of } \\
\text { of Allergies/ } \\
\text { Manifestations }\end{array}$ & $\begin{array}{c}\text { Other } \\
\text { Biologic/ } \\
\text { Hypersensitivity }\end{array}$ \\
\hline Patient 1 & F 49 & RA & Etanercept & 9 & 4 & $\begin{array}{l}\text { Soy milk, } \\
\text { angioedema }\end{array}$ & None \\
\hline Patient 2 & F 27 & AOSD & Etanercept & 24 & $\mathrm{Pe}$ & $\begin{array}{l}\text { Penicillin, pruritic rash, } \\
\text { chest tightness, } \\
\text { shortness of breath }\end{array}$ & Abatacept, none \\
\hline Houtman $^{2}$ & F 46 & RA & $\begin{array}{l}\text { Probably MTX, } \\
\text { perhaps "provoked" } \\
\text { by etanercept }\end{array}$ & 168 & 6 & None reported & $\begin{array}{l}\text { Probably MTX } \\
\text { hypersensitivity }\end{array}$ \\
\hline Moore $^{3}$ & F 44 & RA & Etanercept & NA & 3 injections & Facial swelling & $\begin{array}{c}\text { Failed } 3 \text { unspecified } \\
\text { DMARD }\end{array}$ \\
\hline Sendur $^{4}$ & F 59 & RA & Etanercept & 96 & $\begin{array}{c}4 \text { mo of twice- } \\
\text { weekly injections }\end{array}$ & None & $\begin{array}{l}\text { None reported; } \\
\text { failed MTX, prednisone }\end{array}$ \\
\hline Puxeddu ${ }^{5}$ & NA & NA & $\begin{array}{l}\text { Infliximab ( } 21 \text { patients, } \\
\text { anaphylaxis; } 10 \text {, urticaria/ } \\
\text { angioedema) adalimumab } \\
\text { (3 patients, urticaria/ } \\
\text { angioedema) }\end{array}$ & NA & NA & Anaphylaxis & \\
\hline Abadoglu ${ }^{11}$ & F 46 & RA & Anakinra & NA & $\begin{array}{c}\text { Failed MTX, } \\
\text { prednisone, } \\
\text { sulfasalazine, HCQ, } \\
\text { infliximab (urticaria), } \\
\text { etanercept }\end{array}$ & $\begin{array}{c}\text { Perioral and } \\
\text { facial swelling, } \\
\text { shortness of } \\
\text {, breath, urticaria }\end{array}$ & \\
\hline Bertacini $^{12}$ & F 32 & RA & Rituximab & NA & & $\begin{array}{l}\text { Generalized pruritic } \\
\text { popular urticaria; } \\
\text { dizziness, tachycardia, } \\
\text { loss of consciousness }\end{array}$ & \\
\hline
\end{tabular}

AOSD: adult-onset Still's disease; NA: not available; DMARD: disease-modifying antirheumatic drug; HCQ: hydroxychloroquine; MTX: methotrexate; NA: not available.

Personal non-commercial use only. The Journal of Rheumatology Copyright @ $\odot$ 2012. All rights reserved. 
anaphylaxis or angioedema associated with etanercept ${ }^{9}$. And colleagues had not encountered patients with this response to a TNF- $\alpha$ antagonist.

However, there have been reports of adverse effects (Table 1). A patient taking methotrexate and etanercept manifested urticaria, macular rash, periorbital and general facial edema, and a $30 \mathrm{~mm} \mathrm{Hg}$ fall in blood pressure on 2 occasions associated with subcutaneous methotrexate (but not etanercept), and had intracutaneous hypersensitivity to methotrexate ${ }^{2}$. Angioedema was reported in a patient 2 days after her third injection of etanercept ${ }^{3}$. Angioedema occurred in another patient 4 months after starting etanercept ${ }^{4}$. A letter reported hypersensitivity reactions among 671 patients with RA, spondyloarthropathy, ankylosing spondylitis, psoriatic arthritis, Behçet disease, and Crohn disease who were treated with antiTNF agents. It appeared that 13 who received etanercept had atopic reactions: 5 urticaria/angioedema, 2 anaphylaxis, 4 local, and 2 other (pruritis, rash, eosinophilia). The authors said that 31 patients taking infliximab and 3 taking adalimumab reported anaphylaxis, urticaria, or angioedema ${ }^{5}$. We were able to identify only 2 reports of similar reactions to other biologic agents (anakinra and rituximab) for patients with rheumatic diseases ${ }^{10,11}$ (Table 1).

We can only speculate about the source of the allergic response to etanercept. Antichimeric antibodies (infliximab) may lead to more acute allergic reactions ${ }^{9}$. Fusion proteins (etanercept) induce a weaker immune response ${ }^{4,12}$. We do not know whether our patients' responses were mediated by $\operatorname{IgE}$ or IgG or whether antibodies had developed against the "hinge/fusion" region of the molecule $13,14,15$.

Etanercept allergy presents some management implications. Attempting desensitization was not feasible for our patients. Lyophilized medication could have been administered in other diluents, and/or administered in escalating and divided dosages. It might have been of interest to see if administration of other TNF- $\alpha$ antagonists was tolerated ${ }^{5}$. We preferred to avoid the potential risks of these challenges and to consider other, nonbiological treatments. Certainly the simplest and most practical approach was to use other (non-TNF- $\alpha$ antagonist) disease-modifying antirheumatic agents for our patients, which is what we did.

ANNE QUISMORIO, MD, MPH, Postdoctoral Fellow, Division of Rheumatology, Department of Medicine, Keck School of Medicine, University of Southern California, and Los Angeles County + University of Southern California (LAC + USC) Medical Center, Los Angeles, California; BHAUMIK BRAHMBHATT, MD, Senior Assistant Resident, Department of Medicine, Saint Barnabas Medical Center, University of Medicine and Dentistry of New Jersey-New Jersey Medical School, Livingston, New Jersey; MINDY HOUNG, MD, Assistant Program Director, Department of Medicine, Saint Barnabas Medical Center, Assistant Professor of Medicine, Department of Medicine, University of Medicine and Dentistry of New Jersey-New Jersey Medical School; RICHARD S. PANUSH, MD, MACP, MACR, Professor, Division of Rheumatology and Immunology, Department of Medicine, Keck School of Medicine, University of Southern California, LAC + USC Medical Center, Los Angeles, California, USA (formerly, Professor and Chair, Department of Medicine, Saint Barnabas Medical Center, University of Medicine and Dentistry of New Jersey-New Jersey Medical School, Livingston, NJ). Address correspondence to Dr. R.S. Panush, 2011 Zonal Ave., HMR 711, Keck School of Medicine, University of Southern California, Los Angeles, CA 90032, USA. E-mail: panush@usc.edu

\section{REFERENCES}

1. Enbrel ${ }^{\circledR}$ (etancercept) prescribing information. Immunex Corporation, Thousand Oaks, CA. October 2003.

2. Houtman PM, Jansen TL, Blanken R. Anaphylactic reaction in a patient with rheumatoid arthritis: A rare side effect of methotrexate with etanercept as a provoking factor? J Clin Rheumatol 2006;12:321-2.

3. Moore S, Palmer D, Kallarackal G. Beware angioedema with etanercept. Abstract 445. Rheumatology 2008;47:129.

4. Sendur OF, Turan Y, Berkit IK, Tastaban E. Angio-oedema in a patient treated with etanercept for rheumatoid arthritis. Basic Clin Pharmacol Toxicol 2009;104:488-90.

5. Puxeddu I, Giori L, Rocchi V, Bazzichi L, Bombardieri S, Tavoni A, et al. Hypersensitivity reactions during treatment with infliximab, etanercept, and adalimumab. Ann Allergy Asthma Immunol 2012;108:123-4.

6. Kerensky T, Gottlieb A, Yaniv S, Au S. Etanercept: efficacy and safety for approved indications. Expert Opin Biol Ther 2012;11:121-39.

7. Moreland LW, Weinblatt ME, Keystone EC, Kremer JM, Martin RW, Schiff MH, et al. Etanercept treatment in adults with established rheumatoid arthritis: 7 years of clinical experience. J Rheumatol 2006;33:854-61.

8. Fleischmann R, Baumgartner SW, Weisman MH, Liu T, White B, Peloso P. Long term safety of etancercept in elderly subjects with rheumatic diseases. Ann Rheum Dis 2006;65:379-84.

9. du Pan SM, Dehler S, Curea A, Ziswiler H, Gabay C, Finck A. Comparison of drug retention rates and causes of drug discontinuation between anti-tumor necrosis factor agents in rheumatoid arthritis. Arthritis Rheum 2009;61:560-8

10. Desai D, Goldbach-Mansky R, Milner JD, Rabin RL, Hull K, Pucino F, et al. Anaphylactic reaction to anakinra in a rheumatoid arthritis patient intolerant to multiple nonbiologic and biologic disease-modifying drugs. Ann Pharmacother 2009;43:967-72.

11. Abadoglu O, Epozturk K, Atayik E, Kaptanoglu E. Successful rapid rituximab desensitization for hypersensitivity reactions to monoclonal antibodies in a patient with rheumatoid arthritis: A remarkable option. J Invest Allergol Clin Immunol 2011;21:319-21.

12. Bertacini de Moraes J, Aikawa N, de Medeiros Ribeiro A, Saad C, de Carvalho J, Pereira R, et al. Immediate complications of 3,555 injections of anti-TNF alpha. Bras J Rheumatol 2010;50:165-75.

13. Thalayasingam N, Isaacs JD. Anti-TNF therapy. Best Pract Res Clin Rheumatol 2011;25:549-67.

14. Anderson P, Louie J, Lau A, Broder M. Mechanisms of differential immunogenicity of tumor necrosis factor inhibitors. Curr Rheumatol Rep 2005;7:3-9.

15. Anderson P. Tumor necrosis factor inhibitors: Clinical implications of their different immunogenicity profiles. Semin Arthritis Rheum 2005;5 Suppl 1:19-22.

J Rheumatol 2012;39:11; doi:10.3899/jrheum.120791 